illustrations reproduced from photographs. ${ }^{1}$ Notwithstanding the observations of Russegger, Fraas, and others, on the physical features and structure of this region, a complete monograph on its geology has long been a desideratum, and the work of Dr. C. Diener forms a fitting continuation of the survey of Lartet in Palestine, and of the Palestine Exploration Society in Arabia Petræa and the Jordan Valley.

Down to a comparatively recent period, the ranges of the Lebanon and Anti-Lebanon were supposed to be formed of Jurassic limestones, but the observations of Oscar Fraas showed that this was an error, and that they are mainly formed of Cretaceous and Eocene limestones. It is only within the limits of a narrow belt at the western base of Mount Hermon that Jurassic beds really occur this being their first appearance on proceeding northwards from Arabia Petræa. 'The formations overlying the Jurassic strata are referable to the "Neocomian" (?), Cenomanian, 'Turonian, Senonian, Eocene; and newer Tertiary periods; while great sheets of basaltic lava of late Tertiary age occur both to the north and to the south of the region embraced by the memoir.

Dr. Diener has worked out with great success the numerous lines of faulting and flexuring which the strata have undergone since their deposition, and which have been produced mainly during the Miocene epoch. Mount Hermon itself owes its position in a great degree to the elevation of its mass along the line of a great fault which coincides with its western base. Its beds of limestone, belonging to the age of the Lower Chalk of Europe, are disposed in the form of a low arch, the axis of which passes under the summit, and ranges in a north-northeast direction along the line of the heights of AntiLebanon. Other faults range along the southern and eastern flanks of the great dome-shaped mount which has thus been bodily upheaved in respect of the bordering strata. There can be no question that the system of terrestrial disturbances along which the Syrian mountains have been fractured and dislocated is the same as that which has given origin to the Jordan-Arabah depression; and amongst the lines of displacement traced out by Dr. Diener, we can have no difficulty in recognising that which is the actual prolongation of the leading fault of the Jordan Valley. This great line of fracture and displacement appears to enter the valley of the Leontes (Litany) at the western base of Hermon, where a complete change of the stratification takes place on either side, and the "Lebanon Limestone," with the subordinate Lower Cretaceous beds, are thrown into a nearly vertical position, and brought into contact with horizontal strata of the Upper Chalk (Senonkreide). It may therefore be inferred that the great valley of Cœle-Syria (El Bekâ'a), separating the range of the Lebanon from that of AntiLebanon, owes its origin, in the first instance, to the same system of faults which has caused the depression of the Jordan Valley, the original features having been modified by extensive denudation; and if we suppose that the primary line of fault reaches as far north as the Lake of Homs, in the valley of the Orontes, and as far south as the Gulf of Akabah, the distance through which this great line of fracture of the earth's crust will have been traced will amount to about 350 Euglish miles.

Dr. Diener expresses some doubts regarding the former existence of glaciers in the Lebanon, notwithstanding the opinions of such observers as Hooker, Fraas, Girard, and thers. Hooker especially identifies the mound upon which the grove of ancient ced irs is planted as an ancient moraine. The author throws some doubt upon this view, because he was unable, after three hours of search, to find scratched or striated boulders, although he admits that, viewed in certain directions, the mounds do present the appearance of a terminal moraine. In reference to this 1" "Libanon; Grundlinien der physischen Geographie und Geologie von
Mittel-Syrien." (Wien, 1886.) subject, it may be observed that the position and altitufe of the Lebanon Range makes it extremely probable that perennial snow, giving origin to glaciers, occupied the higher regions during the Glacial epoch. Am ongst the Caucasus, which are only a few degrees further north, though somewhat higher, glaciers occur at the present day, and during the Glacial epoch the valleys were brimful of ice. Hence it would be strange if in the Lebanon it were proved that they had been entirely absent. The scarcity or absence of glacial striations, on which Dr. Diener founds his objection, is easily accounted for when we recollect that the blocks and stones consist of rather friable limestone which has been exposed through thousands of years to the effects of frost, heat, and rain. It is only when the surface of a rock, or of a boulder, has been protected by a coat of stiff glacial clay, that we can expect the striæ and scars to be preserved throughout a long period of time.

On another point Dr. Diener expresses his dissent from the views of previous observers, arising, as it seems to the writer, from his want of appreciation of the full effect of eroding agencies. The neck of land which connects the Râs Beyrût with the outer ridges of the Lebanon is formed of beds of stratified gravel or conglomerate rising from 120 to $I 50$ feet above the sea. This is to all appearance an old sea-bed formed at a time when the land was submerged to the extent above indicated, during which Râs Beyrût was an island. The author cannot accept this view, because his observations of the coastline of Syria, bearing on the present state of the harbours, do not appear to show a change of level of more than a few feet; less, in fact, than would be necessary to submerge the neck of land. On the other hand, he accepts the evidence offered by Lartet and the writer of a submergence of the coast of Southern Palestine and Philistia to an extent even greater than this, namely 200 feet and upwards; and he points to the evidence of great changes of level on the coast of Northern Syria and Asia Minor. May not the absence of raised beaches on the coast of Southern and Middle Syria be due to the waste caused by the wave action of the Mediterranean, which would tend to carry away such soft materials during the period of emergence where exposed and unprotected? In another case the author throws doubt on the observations of Dr. Post regarding the presence of shell-beds at levels of 150 to 250 feet near Lâdikîeh, an account of which appeared in NATURE, vol. xxx. p. 385 , and which is given with much detail. It seem; an instance of hypercriticism to call in question an authenticated statement merely on the ground that the author was unable to personally verify it.

The above instances will, however, go to show with what care and labour Dr. Diener has accomplished his task, and he is to be congratulated upon the production of a work which will doubtless $b=$ considered a standard of reference regarding the physical history of the Syrian mountains. I may perhaps be allowed to rem urk that his admirable geological map would have been improved by following the English custom of showing the dip of the strata by means of small arrows, and of distinguishing between ordinary boundaries of formations and those which are produced by faults and fractures, and the book itself would have been rendered easier for reference by an index.

EDWATR HULL

\section{AUTUMNAL FLOWERING}

THE "extraordinary gooseberry" season seems to have set in this year with more than usual severity. Country clergymen and amateur gardeners, who would see nothing unusual in the autumnal flowering of a hybrid perpetual rose (which reminds them, perhaps, of their old school-days, when. they read of "biferique 
rosaria P(esti"), are moved with astonishment at the sight of a second crop of flowers on an apple-tree or a laburnum. Common as the phenomenon is, however, not many persons, even among botanists, bestow a thought as to how it is brought about. Gardeners recognise two distinct modes in which flowers may be produced, either from the "old wood," meaning the wood formed in the previous season, or from the shoot of the present year's growth. A rhododendron with its flowers packed up in a "winter-bud" destined to unfold in spring, an apple or a laburnum with their winter-buds at the ends of short contracted shoots or "spurs," afford illustrations of the one type, while a rose, with its newly-formed shoots crowned with one or more rose-buds, supplies an example of the latter. There is the same sort of difference between these two kinds of flowers that there is between the so-called "annual" plants whose course of life is outrun in a single season, and "herbaceous perennials" which die down in winter, leaving a winter-bud to carry on the work when circumstances become propitious in spring. The second growth of flowers in autumn may, therefore, be due to two different causes. In the one case it is an anticipation of spring; the flowers being produced afore time. Conditions of growth being persistently favourable, the winter-bud, instead of remaining dormant, bursts prematurely into growth, and repeats in autumn what its predecessor had done in spring. The great difficulty in such a case is to explain why one bud, or at any rate only a small proportion of the total number of buds, acts in this way when the circumstances of the case would appear to be substantially alike in all. To talk of the individuality of buds is to denote a fact which every observer must be conversant with, but which does not supply any explanation. In the second class of cases the flowers are, as in "hybrid perpetual" roses, placed at the ends of some of the shoots of the year. In this case gardeners have availed themselves of what was originally an occasional tendency to continue the development of flowers on the end of certain shoots, and have, as it were, converted an accidental into a constant occurrence. Doubtless they might do the same in the case of the laburnum, were they so disposed. It is here that the skill of the gardener comes in, and even enables him, to some extent, to baffle adverse climatic influence and induce a plant, as a regular thing, to flower twice in a season, or even more or less continuously, when, if left to itself it would either not do so at all, or only in a fitful, uncertain manner. It is worth notice, too, that these second blooms are often (but by no means invariably) malformed. Some rhododendrons now before me are so, while the doubleflowered apples that one occasionally sees are always, in my experience, formed on the midsummer shoots of the tree. So, again, with pears, the second crop of flowers is usually produced on shoots of the year, and very generally the flowers are more or less imperfect or misshapen. The "Napoleon" pear behaves in this way every year. Every year, too, I am indebted to Mr. Burbidge, of the Trinity College Botanic Garden, Dublin, for specimens of "Bishop's Thumb" pears, produced on the summer shoots. These pears are more like fingers than thumbs, and are destitute of core. The flower-stalk swells up as usual, and produces an eatable pear, but the carpels and seeds are conspicuous by their absence. The developing force has been energetic enough to produce flower- and fruit-stalk, but it has failed in the more essential process of seed- and embryoformation. Possibly in some cases the absence of seed may be the result of want of fertilisation. It may be that in the flowers some at least of the carpels are present with their contained ovules, but, owing to the want of effective fertilisation, they have dwindled away and left no trace.

It would be a curious and important matter to ascertain whether, and to what extent, this repeated flowering process exhausts the plant. If no seed were produced the extra outlay of energy would probably not be severely felt. But every rose-grower knows how great are his losses, and how difficult it is to keep his "standards" in good form and good health. Of course there are many causes for this, but it is not unreasonable to suppose that one of them arises from exhaustion from continuous flowering, which produces a condition that predisposes to disease.

Another phenomenon of a somewhat similar charactex is very commonly met with this autumn, although, not unnaturally, it does not attract so much attention. I allude to the production of buds and leaf-shoots on the partially withered stems of herbaceous perennial plants, such as various species of Epilobium, Malva, \&c. The branches of these plants usually dry up after flowering, leaving only a rosette of leaves or a winter-bud to carry on the growth next season; but occasionally they retain some amount of vitality, and, as at this season, produce a new generation of shoots from the old ones.

These variations show how artificial are the distinctions denoted by the terms annual, perennial, herbaceous, and the like, and they show what a wide range of physiological diversity may exist within the limits of the same species.

Maxwell, T. Masters

\section{ARROW-RELEASE ${ }^{1}$}

$A \mathrm{~T}$ the commencement of this very interesting and A instructive monograph, Prof. Morse tells us that when he began collecting data illustrating the various methods of releasing the arrow from the bow, as practised by different races, he was animated merely by curiosity; nor was it until he had accumulated quite a collection of sketches and other memoranda on the methods of arrowrelease, not only of existing but of ancient races, as shown by frescoes and rock-sculptures, that he realised that even so trivial an art as that of releasing the arrow might possibly lead to interesting results in tracing the affinities of races. Hence he publishes in the present pamphlet the data which he has thus far collected, in the hope that further material may be secured for a more extended memoir on the subject. The great difference which Prof. Morse observed between the ordinary English and Japanese methods of using the bow first led him to investigate the subject, with the curious results to be presently narrated. The various forms of release, with their different modifications, are classified, and perhaps Prof. Morse's investigations may be most succinctly described by using his classification.

(I) Ordinary Release.-This is the simplest form of release, and is that which children all the world over naturally adopt in first using the bow. It consists in simply grasping the arrow between the end of the straightened thumb, and the first and second joints of the bent forefinger (Figs. 1 and 2). With a light or weak bow, says Prof. Morse, this release is the simplest and best; it makes little difference on which side of the bow the arrow rests, provided the bow is held vertically. On the other hand, however, a stiff bow cannot be drawn in this way, unless one possesses enormous strength in the fingers. This simple or primary release is that in use amongst the Ainos of Yezo, by the Demerara Indians, apparenily also by the Utes. The Navajos employ it when shooting at prairie dogs, so that the arrow will not penetrate the ground if it misses its mark; so do the Chippewas. The Micmac Indians of the Cascapedia settlement, on the north shore of the Bay of Chaleur, used it, and it is said that the other tribes in this part of Canada draw the arrow in the same way. A member of the Penobscot tribe at Moosehead Lake, seemed incredulous when Prof.

I "Ancient and Modern Methods of Arrow-Release." By Edward S. Morse, Director Peabody Academy of Science. Essex Institute Bulletm, October-December, 1885 . 